\title{
Response to short term ultraviolet stress in the reef-building coral Pocillopora capitata (Anthozoa: Scleractinia)
}

Marco A. Liñán-Cabelloํㅡㄹ Laura A. Flores-Ramírez ${ }^{1}$, José Francisco Cobo-Díaz ${ }^{2}$, Tania ZentenoSavin $^{3}$, Norma O. Olguín-Monroy ${ }^{3}$, Aramís Olivos-Ortiz ${ }^{1} \&$ Adrián Tintos-Gómez ${ }^{1}$

1. Acuacultura/Biotecnología, FACIMAR, Universidad de Colima, Km 19.5 carretera Manzanillo-Barra de Navidad Manzanillo, Colima, México; Tel/Fax: 314-3311205; linanm@ucol.mx

2. Facultad de Ciencias Biológicas, Universidad Complutense de Madrid, José Antonio Novais Ciudad Universitaria, Madrid; josecobo1983@hotmail.com

3. Centro de Investigaciones Biológicas del Noroeste (CIBNOR), Planeación Ambiental y Conservación, La Paz, Baja California Sur, México; tzenteno04@cibnor.mx

Received 06-III-2009. C Corrected 80-VII-2009. Accepted 18-VIII-2009.

\begin{abstract}
Coral reefs are impacted by a range of environmental variables that affect their growth and survival, the main factors being the high irradiance and temperature fluctuations. Specimens of Pocillopora capitata Verrill 1864 were exposed to photosynthetically active radiation (PAR) and ultraviolet radiation (UVR) for $32 \mathrm{~h}$ under laboratory conditions. We examined lipid peroxidation (MDA), antioxidant enzyme activities (SOD, CAT, GPx and GST), chlorophyll $a(\mathrm{Chl} a$ ), carotenoid pigments (CPs), mycosporine-like amino acids (MAAs), and expulsion of zooxanthellae. Our results revealed that corals exposed to UVR had relatively low levels of carotenoids and antioxidant enzyme activities compared to those exposed to PAR, as well as lower CPs/Chl $a$ ratios. Although MAAs and CPs are rapidly produced as non-enzymatic antioxidants in response to UVR in corals, these were not sufficient, even in the dark phase of the experiment, to mitigate the damage caused by formation of reactive oxygen species (ROS), which caused breakdown of the symbiotic relationship between the zooxanthellae and the host animal to an extent 33 times greater than in the PAR treatment. In this study, it could be possible to distinguish that, parallel to the short-term adjustments, such as the amount of pigment in the algae or the sensitivity of the photosynthetic response reported in other species of coral, $P$. capitata exhibits at the enzymatic level a series of responses oriented to resist the effects derived from the propagation of ROS and, thus, to adapt to and maintain its reproductive capacity in shallow oceanic environments that commonly exhibit high UVR levels. Nevertheless, as a result of the inappropriate location of the artificial intercommunication structure of the Juluapan Lagoon with respect to the arrecifal area of study and therefore of the tides influence, other variables, such as the changes in short-term in turbidity, sediment inputs, nutrients, temperature and osmolarity, can act in combination and cause irreversible damage. The implementation of a management plan for the coralline reefs of the Mexican Pacific coast is required. Rev. Biol. Trop. 58 (1): 103-118. Epub 2010 March 01.
\end{abstract}

Key words: antioxidants, carotenoids, corals, oxidative stress, MAAs, UVR, lipid peroxidation, Pocillopora capitata, photosynthetically active radiation, SOD, CAT, GPx, GST, chlorophyll $a$, reactive oxygen species.

There is great interest in the physiological and ecological consequences of the exposure of coral reef organisms to solar UV radiation (UVR). Of particular concern are the photoautotrophic coral symbionts, which may be subject to photooxidative stress due to excessive
UVR exposure, resulting in coral bleaching. Exposure to UVR can induce the formation of oxygen radicals including singlet oxygen $\left({ }^{1} \mathrm{O}_{2}\right)$, superoxide $\left(\mathrm{O}_{2}^{-}\right)$and hydrogen peroxide $\left(\mathrm{H}_{2} \mathrm{O}_{2}\right)$. These radicals can disrupt protein synthesis and damage cell membranes (Lesser 
1996, Shick et al. 1999), and $\mathrm{H}_{2} \mathrm{O}_{2}$ induces formation of highly reactive hydroxyl radicals $(\cdot \mathrm{OH})$, which may trigger oxidative damagedriven bleaching in coral reefs (Downs et al. 2002).

Corals have various defense mechanisms against photochemical damage from exposure to high temperatures, UVR (Lesser \& Shick 1989) or a combination of both (Lesser 1996, 1997, 2004), including photoactivation of DNA (mediated by UV-A and PAR radiation), nucleotide excision repair and DNA recombination (Mitchell \& Karentz 1993, Van de Poll et al. 2001), the accumulation of lipid- and water-soluble antioxidants, and production of antioxidant enzymes (Cockell \& Knowland 1999). Another physico-chemical mechanism of interest is the biosynthesis and accumulation of sunscreen molecules that prevent the damaging effects of UV radiation. For instance, compounds such as carotenoids, phycobiliproteins, phenols, coumarin, and mycosporinelike amino acids (MAAs) have been found in aquatic organisms (Korbee et al. 2006).

MAAs are low molecular weight, watersoluble compounds with maximum UVR absorption between 310 and $360 \mathrm{~nm}$, which dissipate radiation energy absorbed by heat and fluorescence without generating photochemical reactions (Bandaranayake 1998, Cockell \& Knowland 1999). There are 23 MAAs described in marine organisms, and several studies have found that production and accumulation of MAAs in corals are induced by UVR (Jokiel \& York 1982, Dunlap \& Shick 1998, Lesser 2000) depending on the quality and quantity of radiation delivered (Carreto et al. 1990, Riegger \& Robinson 1997, Karsten et al. 1998). There is experimental evidence that these compounds protect corals from solar UVR (Kinzie 1993, Torregiani \& Lesser 2007). In addition, some MAAs are known to be effective quenchers of ROS, the production of which increases with increasing exposure to UVR (Lesser 2006). In particular, mycosporine-glycine (Myc-Gly), the dominant MAA in various marine organisms, is considered to have moderate antioxidant potential (Dunlap \& Yamamoto 1995).
In vitro experiments have shown that inhibition of lipid peroxidation, which gives rise to malondialdehyde (MDA) as the most abundant product, in marine organisms (Dunlap \& Yamamoto 1995) and the elimination of ROS generated by some endogenous photosynthetic organisms (Suh et al. 2003) are dependent on the concentration of MAAs including MycGly and its functional analog, mycosporinetaurin. ROS attack membrane lipids, initiating a process of autocatalytic oxidation known as lipid peroxidation or lipoperoxidation. During this process oxidation of lipids generates lipid hydroperoxides $(\mathrm{LOOH})$, and their formation in membranes disrupts normal cell metabolism, triggering adaptive responses and/or causing cell death (Girotti 1998).

In this study we investigated the effect of UVR on biochemical responses associated with photosynthetic pigments, photoprotectors and markers of oxidative stress during an experimental short-term exposure to UVR, inducing zooxanthellae expulsion. The information obtained from this study will contribute to understand imbalances in symbiotic processes that characterize the phenomenon of coral bleaching.

\section{MATERIALS AND METHODS}

Study site and sample collection: Samples of the coral Pocillopora capitata Verrill, 1864 were collected from a reef in the Bay of Santiago (La Boquita) in Manzanillo, Colima, Mexico, where coral patches cover an area of $3,876.2 \mathrm{~m}^{2}$ at depths of $0.5-3.5 \mathrm{~m}$. On this area, Pocillopora, Porites and Pavona are the richest genus in terms of species abundance (ReyesBonilla et al. 2005). This habitat is subject to intense and constant stressors including input of sediment, and warm water with high salinity from the Juluapan lagoon because a small jetty that leads to the exchange of water masses was constructed in 2003 between the sea and the lagoon, adjacent to the north-west margin of the reef $19^{\circ} 06^{\prime} 13.85^{\prime \prime}-19^{\circ} 06^{\prime} 12.08^{\prime \prime} \mathrm{N}$, and $104^{\circ} 23$ '49.180"-104²3'45.810" W (Fig. 1). 


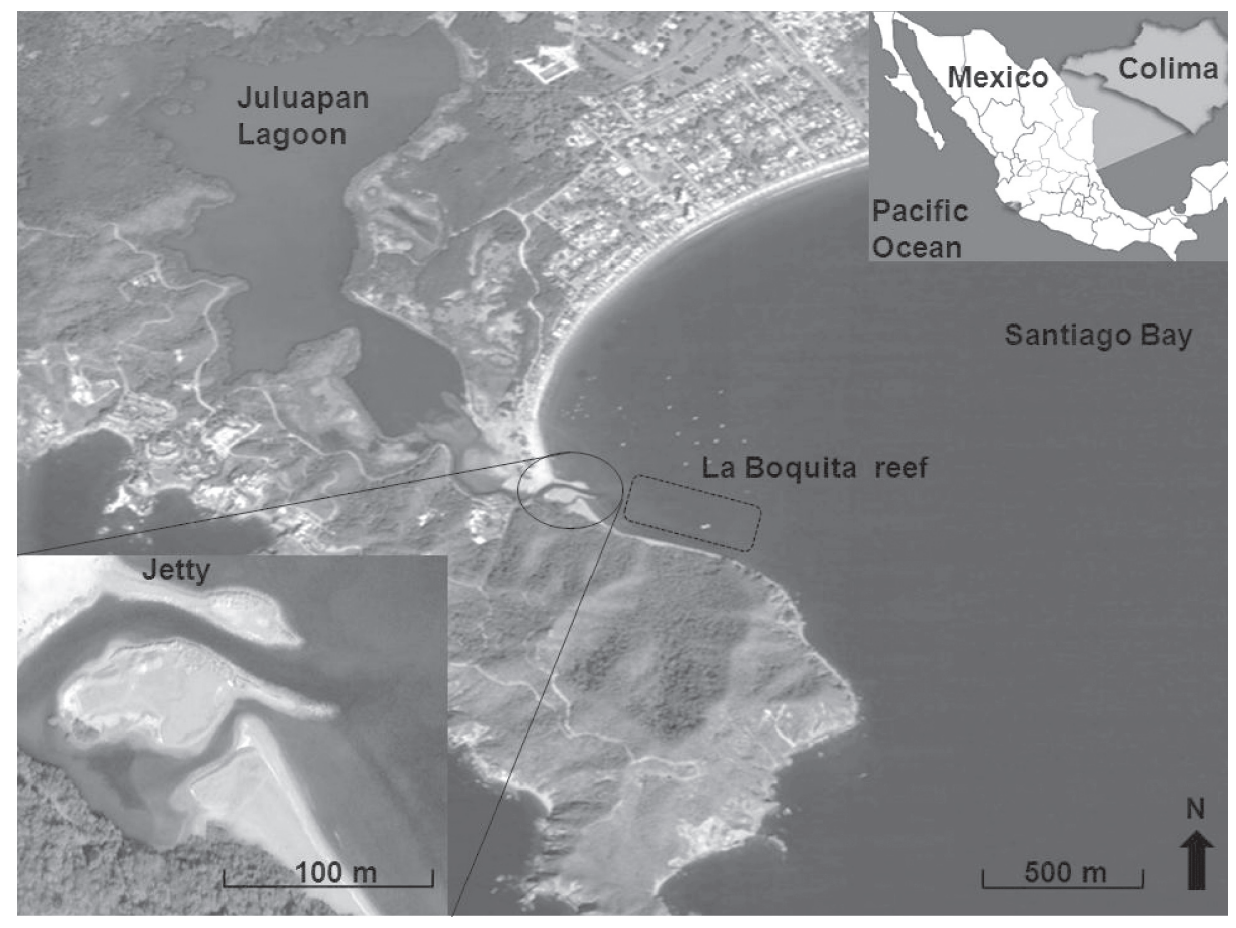

Fig 1. Location of study site and of the artificial intercommunication structure with the Juluapan lagoon in the Santiago bay in Manzanillo, Col., México.

During July of 2007, individual branches of $P$. capitata that showed no apparent bleaching damage were collected from the reef at $1.2 \mathrm{~m}$ depth within $35 \mathrm{~m}$ of the jetty. The branches $(10 \times 10 \mathrm{~cm})$ were collected and transported to the laboratory of Facultad de Ciencias Marinas (FACIMAR, Universidad de Colima, México), in $10 \mathrm{~L}$ buckets containing ambient seawater, and immediately transferred to the aquarium and kept at $25^{\circ} \mathrm{C}$ and $35 \%$ salinity for one hour to minimize the influence of collection stress prior to experimentation. We examined markers of oxidative stress including lipid peroxidation (MDA), antioxidant enzyme acivities (SOD, CAT, GPX, GST), as well as levels of chlorophyll $a(\mathrm{Chl} a)$, carotenoid pigment (CPs) levels, and expelled zooxanthellae.

Experimental design: The coral branches were randomly assigned to one of two treatments ( $n=14$ per treatment) under each light unit. One coral group was exposed to visible light using $2 \times 15 \mathrm{~W}$ daylight lamps (wavelength range $\left.=400-700 \mathrm{~nm}, 156 \mu \mathrm{mol} \mathrm{m}^{-2} \mathrm{~s}^{-1}\right)$, this value is within the range of $179.8 \pm 81.3 \mu \mathrm{mol} \mathrm{m}^{-2} \mathrm{~s}^{-1}$ considered to be the light field average by Anthony et al. (2007), in a natural population of coral Acropora intermedia, these values are typical in the early hours of the study site (data not shown). A second treatment group was exposed to ultraviolet light (predominantly UV-B but including all UV-A wavelengths) using $6 \times 8 \mathrm{~W}$ UVR fluorescent lamps $\left(\lambda_{\max }=310\right.$ $\mathrm{nm}, 5.23 \mathrm{Wm}^{-2}$; Ultra-Violet Products, Ltd, UK). This group was covered with a $20 \times 20 \mathrm{~cm}$ cut-off filter which was used to attenuate the shorter wavelengths. The UVR value was similar to the average recorded in the morning on a clear day at the study site $\left(5.7 \mathrm{Wm}^{-2}\right)$, during the month prior to collection measured using a Mannix UV-340 ultraviolet light meter (290390nm). 
The experiment was initiated in the light phase of the photoperiod (10h light:14h dark), and was conducted over $32 \mathrm{~h}$ with constant aeration in culture flasks containing $800 \mathrm{~mL}$ of filtered and sterilized seawater at $25^{\circ} \mathrm{C}$ (the water temperature at the sampling site) in a light-controlled environmental chamber (REVCO, Scientific Inc, USA). Samples from each treatment group were removed at $0,2,4$, $7,10,24,28$ and $32 \mathrm{~h}$, wrapped in aluminum foil and stored at $-70^{\circ} \mathrm{C}$ for use in the assay described below. Samples were only taken at 0 , 4, 24 and 32h for antioxidant enzyme activity assays.

Determination of chlorophyll $a$ and carotenoid levels: Tissues were removed from the coral skeleton using compressed air in place of water pressure as required in the WaterPik ${ }^{\mathrm{TM}}$ method (Johannes \& Wiebe 1970). The resulting slurry was homogenized for $30 \mathrm{~s}$ in $100 \mathrm{~mL}$ of filtered seawater in a blender. To determine the chlorophyll $a(\mathrm{Chl} a$ ) content, $10 \mathrm{~mL}$ of homogenate was mixed with $0.1 \mathrm{~g}$ of $\mathrm{MgCO}_{3}$ and centrifuged at $2000 \times \mathrm{g}(\mathrm{n}=3)$. The supernatant was discarded and the algal pellet was resuspended in $10 \mathrm{~mL} 100 \%$ acetone and incubated at $2{ }^{\circ} \mathrm{C}$ for $24 \mathrm{~h}$. The sample was centrifuged again $(2000 \times \mathrm{g}, 10 \mathrm{~min})$ and the absorbance of the supernatant was determined at 630,647 and $664 \mathrm{~nm}$ using a Genesys 5 spectrophotometer ${ }^{\mathrm{TM}}$ (Spectronic Instruments, Rochester, NY, USA). The data were corrected for homogenate volume, and coral surface area was calculated assuming the coral to have a cylindrical shape according to the formula: $\mathrm{A}=2 \mathrm{rh}+2 \mathrm{r}^{2}$, where $\mathrm{A}=$ branch surface area $\left(\mathrm{cm}^{2}\right), \mathrm{r}=$ branch radius (cm) and $\mathrm{h}=$ branch maximum height $(\mathrm{cm})$ (Murguía-Vega \& Reyes-Bonilla 1999). The concentration of Chl $a\left(\mu \mathrm{gcm}^{-2}\right)$ in each sample was calculated using the equation of Parsons et al. (1984). The concentration of carotenoid pigments was determined under semi-darkness conditions as previously described (Sommer et al. 1992). Briefly, $10 \mathrm{~mL}$ of homogenate was centrifuged a $2000 \times \mathrm{g}$ for $10 \mathrm{~min}(\mathrm{n}=3)$ and the pellet was mixed with $10 \mathrm{~mL} 100 \%$ acetone and incubated at $2{ }^{\circ} \mathrm{C}$ for $24 \mathrm{~h}$. The sample was then centrifuged at $2000 \times \mathrm{g}$ for $10 \mathrm{~min}$, and the absorbance of the supernatant was determined at $466 \mathrm{~nm}$ in a spectrophotometer (Spectronic Instruments, Genesys $5^{\mathrm{TM}}$ ). Data were corrected for homogenate volume and coral surface area, and CPs concentrations $\left(\mu \mathrm{gcm}^{-2}\right)$ were obtained using the molar extinction coefficient of peridinin pigment, which comprises $60-70 \%$ of the total pigment in coral zooxanthellae (Borneman 2001).

Expulsion of zooxanthellae: To calculate changes in zooxanthellae expulsion in response to UVR and PAR, $10 \mathrm{~mL}$ of the surrounding water was sampled from each flask at the sampling times specified above and fixed in $4 \%$ formol. The zooxanthellae were counted using a Neubauer camera and results were expressed as cellsmL $L^{-1}(\mathrm{n}=8)$.

Tissue homogenates: Previous to determinations of enzyme activity, proteins and malondialdehyde levels, tissues of coral fragments were removed using the compressed air method described above. The tissues were dissolved in nine volumes of extraction buffer $(20 \mathrm{mM}$ phosphate buffer, $\mathrm{pH} 7.4,1 \mathrm{mM}$ EDTA, $0.1 \%$ Triton X-100) and the resulting crude extract was sonicated $(6 \times 10 \mathrm{~s})$ and centrifuged $(12,000 \times \mathrm{g}$ for $5 \mathrm{~min})$, and the supernatant was stored at $-70^{\circ} \mathrm{C}$ until analysis. All chemicals were obtained from Sigma-Aldrich (St. Louis, MO).

Superoxide dismutase: Total superoxide dismutase (SOD) activity was measured spectrophotometrically using xanthine/xanthine oxidase as a $\mathrm{O}_{2}^{-}$generating system and nitroblue tetrazolium (NBT) as a detector (Suzuki 2000). Each sample was diluted 1:10 with phosphate buffer $(50 \mathrm{mM}$, pH 7.5, EDTA 1mM). Sodiumcarbonate working solution $(50 \mathrm{mM}$, xanthine $0.1 \mathrm{mM}$, NBT $0.025 \mathrm{mM}$, EDTA $0.1 \mathrm{mM}$ ), xanthine oxidase $\left(0.1 \mathrm{UmL}^{-1}\right.$ in ammonium sulfate $2 \mathrm{M}$ ) and sample or blank (phosphate buffer $50 \mathrm{mM}, \mathrm{pH} 7.5$; EDTA $1 \mathrm{mM}$ ) were mixed in a cuvette. The change in absorbance per minute at $560 \mathrm{~nm}\left(\triangle A_{560}\right)$ was calculated. Enzymatic activity was expressed in units of SOD activity 
per mg of protein. One unit of SOD activity is defined as the amount of enzyme needed to inhibit the reaction of $\mathrm{O}_{2}^{-}$, with NBT by $50 \%$.

Catalase: Catalase (CAT) activity was evaluated by measuring the decrease in $\mathrm{H}_{2} \mathrm{O}_{2}$ concentration at 240nm (Aebi 1984). Working solution (phosphate buffer $100 \mathrm{mM} ; \mathrm{H}_{2} \mathrm{O}_{2}$ $10 \mathrm{mM}$ ) and sample were mixed in a cuvette. The change in absorbance per minute at $240 \mathrm{~nm}$ $\left(\Delta A_{240}\right)$ was calculated. Enzyme activity was expressed in units of CAT activity per mg of protein. One unit of CAT activity is defined as the amount of enzyme needed to reduce $1 \mu \mathrm{mol}$ $\mathrm{H}_{2} \mathrm{O}_{2} \min ^{-1}$.

Glutathione peroxidase: Seleniumdependent glutathione peroxidase (GPx) activity was measured by monitoring the continuous decrease in NADPH concentration using $\mathrm{H}_{2} \mathrm{O}_{2}$ as a substrate (Flohé \& Günzler 1984). In a cuvette, potassium phosphate buffer $(500 \mathrm{mM})$, EDTA $(50 \mathrm{mM})$, sodium azide $(20 \mathrm{mM})$, glutathione reductase $\left(15 \mathrm{UmL}^{-1}\right)$, NADPH $(1.5 \mathrm{mM})$, reduced glutathione $(250 \mathrm{mM})$, sample and $\mathrm{H}_{2} \mathrm{O}_{2}(10 \mathrm{mM})$ were mixed; the absorbance was followed at $340 \mathrm{~nm}$, and the change in absorbance per minute $\left(\triangle A_{340}\right)$ was calculated. Two blanks, one without $\mathrm{H}_{2} \mathrm{O}_{2}$ and another without sample, were run simultaneously. Enzyme activity was expressed in units of GPx activity per mg of protein. One unit of GPx activity is defined as the amount of enzyme that oxidizes $1 \mu \mathrm{mol}$ of NADPH $\mathrm{min}^{-1}$.

Glutathione-S-transferase: GlutathioneS-transferase (GST) activity was determined by monitoring the formation of the thioether product from the reaction between GSH and 1-chloro, 2,4-dinitrobenzene (CDNB) (Habig \& Jakoby 1981). Working solution (phosphate buffer 100mM, GSH 1mM, EDTA $60 \mathrm{mM}$ ), CDNB (10mM) and sample were placed in a cuvette and mixed. Absorbance was followed at $340 \mathrm{~nm}$, and the change in absorbance per minute $\left(\Delta A_{340}\right)$ was calculated. One blank was run in absence of sample. Enzyme activity was expressed in units of GST activity per $\mathrm{mg}$ of protein. One unit of GST activity is defined as the amount of enzyme that synthesizes $1 \mu \mathrm{mol}$ of product $\mathrm{min}^{-1}$.

Protein assay: Soluble protein content in tissue homogenates was measured following the method of Bradford (1976) using the BioRad $^{\odot}$ prepared reagent and bovine serum albumin as standard.

Malondialdehyde (MDA): The levels of malondialdehyde (MDA), a product of lipid peroxidation, were evaluated by reaction with thiobarbituric acid (TBA) at 535nm (Buege \& Aust 1978). Briefly, $1 \mathrm{~mL}$ samples $(\mathrm{n}=3)$ were mixed with a solution containing $15 \%(\mathrm{w} / \mathrm{v})$ trichloroacetic acid (TCA), $0.375 \%(\mathrm{w} / \mathrm{v}) \mathrm{TBA}$ and $0.25 \mathrm{~N} \mathrm{HCl}$, and incubated for $20 \mathrm{~min}$ at $90^{\circ} \mathrm{C}$ in a water bath. The samples were cooled to room temperature and centrifuged for $20 \mathrm{~min}$ at $2000 \times \mathrm{g}$. After centrifugation the supernatant was measured spectrophotometrically at $535 \mathrm{~nm}$ against a blank composed of $2 \mathrm{~mL}$ of the TBA/TCA/HCl mixture and $1 \mathrm{~mL}$ of extraction buffer. The results were expressed as $\mu$ mol of MDA per gram of protein ( $\mu \mathrm{mol} \mathrm{g^{-1 }}$ protein).

\section{Mycosporine-like amino acids (MAAs):} For all samples, MAAs were extracted from the remaining pieces of coral according to the modified procedure of Shick et al. (1992). For total MAA concentrations, coral samples $(n=29)$ were cleaned of epiphytes, broken into small pieces, and extracted overnight at $4{ }^{\circ} \mathrm{C}$ in $5 \mathrm{~mL}$ of $100 \%$ HPLC-grade methanol, this extraction method has been previously used for corals (Shik et al. 1999, Lesser \& Farrel 2004, Banaszak et al. 2006). The samples were centrifuged for $5 \mathrm{~min}$ at $10,000 \times \mathrm{g}$ and the supernatant decanted. To detect MAA the supernatant was scanned (280-400nm) on a Lambda 35 spectrophotometer (Perkin Elmer) using quartz cuvettes ( $1 \mathrm{~cm}$ path length). MAA quantification was assessed from the peak height at the wavelength of greatest absorbance (determined to be $325 \mathrm{~nm}$ ) using the molar extinction coefficient of 36200 reported by Bandaranayake (1998), obtained with palythine (principal MAA of $P$. 
capitata) (J.I. Carreto 2009, pers. comm.) and normalized to soluble protein. Changes in total MAA concentration during PAR and UVR exposure from time 0 to $32 \mathrm{~h}$ were expressed as picomoles of MAA per gram of protein (pmol g-1 protein). Protein measurements were measured as described above.

Statistical analyses: Data were analyzed for comparison among sampling times in each treatment and among the average of different light treatments by one-way non-parametric and parametric analysis of variance (ANOVA), followed by a simple/pairwise comparisons test (Sheskin 1996) or in some cases, by a multiple comparison test (Tukey). Where appropriate, ratios were arcsine- or log-transformed for analysis, this transformation is necessary to meet parametric analyses constraints, and back-transformed for presentation. Results are presented as the mean $\pm \mathrm{SD}$, and differences were considered statistically significant at the $\mathrm{p}<0.05$ level.

\section{RESULTS}

Data obtained at different sampling times during the experiment are presented in Table 1 and Figs. 2A, 2B, 3 and 4. No marker enzyme activities varied with light intensity $(\mathrm{p}>0.05)$.
The differences between light treatments are summarized in Table 2 and highlight significant variations in $\mathrm{Chl} a, \mathrm{CPs}, \mathrm{CPs} / \mathrm{Chl} a$ ratio, MAA levels, MDA concentration, and SOD levels $(\mathrm{p}<0.05)$.

Expulsion of zooxanthellae: With either treatment an increase in the level of expulsion was detected at $10 \mathrm{~h}$; further differences were seen after $24 \mathrm{~h}$ of exposure to different light sources (Figs. 2A, B), and expulsion continued to increase exponentially until the end of the experimental period $\left(493 \times 10^{3}\right.$ cells $\mathrm{mL}^{-1}, \mathrm{SD}=104.63, \mathrm{n}=8$ at $32 \mathrm{~h}$ ). Corals in the PAR treatment showed relatively low rates of zooxanthellae expulsion, which peaked at $32 \mathrm{~h}$ $\left(15 \times 10^{3}\right.$ cells $\left.\mathrm{mL}^{-1}, \mathrm{SD}=4.6, \mathrm{n}=8\right)$. However, marked differences $(\mathrm{p}<0.05)$ were apparent between the different treatments, with the expulsion level being 33-fold greater in corals exposed to UVR than to PAR. Additionally, regression analysis between zoo/Chl a in both treatments presented a significant inverse relationship $\left(\mathrm{R}^{2}=-0.80\right)$ only in PAR treatment.

Photosynthetic pigments: In the PAR treatment, Chl a concentration was significantly different between the first hours of the experiment $(0-4 \mathrm{~h})$ and the second part (7-32h) with no change in CP. For the UVR

TABLE 1

Concentration of photosynthetic pigments $\left(\mu \mathrm{g} \mathrm{cm}^{-2}\right)$ and $C P S / C h l$ a ratios in $\mathrm{P}$. capitata exposed to PAR and UVR light over $32 \mathrm{~h}$

\begin{tabular}{|c|c|c|c|c|c|c|}
\hline \multirow{3}{*}{$\begin{array}{l}\text { Exposure } \\
\text { time (h) }\end{array}$} & \multicolumn{3}{|c|}{ PAR } & \multicolumn{3}{|c|}{ UVR } \\
\hline & Chl $a$ & CPs & Ratio & Chl $a$ & $\mathrm{CPs}$ & Ratio \\
\hline & $\left(\mu \mathrm{g} \mathrm{cm}^{-2}\right)$ & $\left(\mu \mathrm{g} \mathrm{cm}^{-2}\right)$ & $(\mathrm{CPs} / \mathrm{Chl} a)$ & $\left(\mu \mathrm{g} \mathrm{cm}^{-2}\right)$ & $\left(\mu \mathrm{g} \mathrm{cm}^{-2}\right)$ & $(\mathrm{CPs} / \mathrm{Chl} a)$ \\
\hline 0 & $14.38 \pm .98^{\mathrm{a}}$ & $0.54 \pm .14^{\mathrm{a}}$ & $0.04^{\mathrm{a}}$ & $14.38 \pm .98^{\mathrm{a}}$ & $0.54 \pm .14^{\mathrm{a}}$ & $0.04^{\mathrm{a}}$ \\
\hline 2 & $13.46 \pm 5.38^{\mathrm{a}}$ & $0.75 \pm .26^{\mathrm{a}}$ & $0.06^{\mathrm{a}}$ & $12.22 \pm 1.58^{\mathrm{a}}$ & $0.19 \pm .01^{\mathrm{b}}$ & $0.02^{\mathrm{a}}$ \\
\hline 4 & $20.52 \pm 4.42^{\mathrm{ac}}$ & $0.93 \pm .32^{\mathrm{a}}$ & $0.05^{\mathrm{a}}$ & $12.70 \pm .59^{\mathrm{a}}$ & $0.18 \pm .02^{b}$ & $0.01^{\mathrm{a}}$ \\
\hline 7 & $5.32 \pm .55^{\mathrm{b}}$ & $0.40 \pm .06^{\mathrm{a}}$ & $0.07^{\mathrm{a}}$ & $11.33 \pm 5.05^{\mathrm{a}}$ & $0.15 \pm .06^{\mathrm{b}}$ & $0.01^{\mathrm{a}}$ \\
\hline 10 & $7.30 \pm 1.64^{b}$ & $0.55 \pm .09^{\mathrm{a}}$ & $0.08^{\mathrm{a}}$ & $16.07 \pm 4.39^{\mathrm{a}}$ & $0.23 \pm .02^{b}$ & $0.01^{\mathrm{a}}$ \\
\hline 24 & $5.11 \pm .78^{\mathrm{b}}$ & $0.48 \pm .07^{\mathrm{a}}$ & $0.09^{\mathrm{a}}$ & $14.33 \pm 4.94^{\mathrm{a}}$ & $0.25 \pm .07^{b}$ & $0.02^{\mathrm{a}}$ \\
\hline 28 & $7.55 \pm 3.85^{\mathrm{b}}$ & $0.46 \pm .06^{\mathrm{a}}$ & $0.06^{\mathrm{a}}$ & $8.11 \pm 1.92^{\mathrm{a}}$ & $0.11 \pm .01^{\mathrm{b}}$ & $0.01^{\mathrm{a}}$ \\
\hline 32 & $7.45 \pm 1.15^{b}$ & $0.62 \pm .09^{\mathrm{a}}$ & $0.08^{\mathrm{a}}$ & $19.24 \pm 10.59^{\mathrm{a}}$ & $0.09 \pm .02^{b}$ & $0.004^{b}$ \\
\hline
\end{tabular}

Data are mean $\pm \mathrm{SE}(\mathrm{n}=3)$. Means with different superscripts in the same column are significantly different $(\mathrm{P}<0.05)$. Chl $\mathrm{a}=$ chlorophyll a, CPs $=$ carotenoid pigments. 

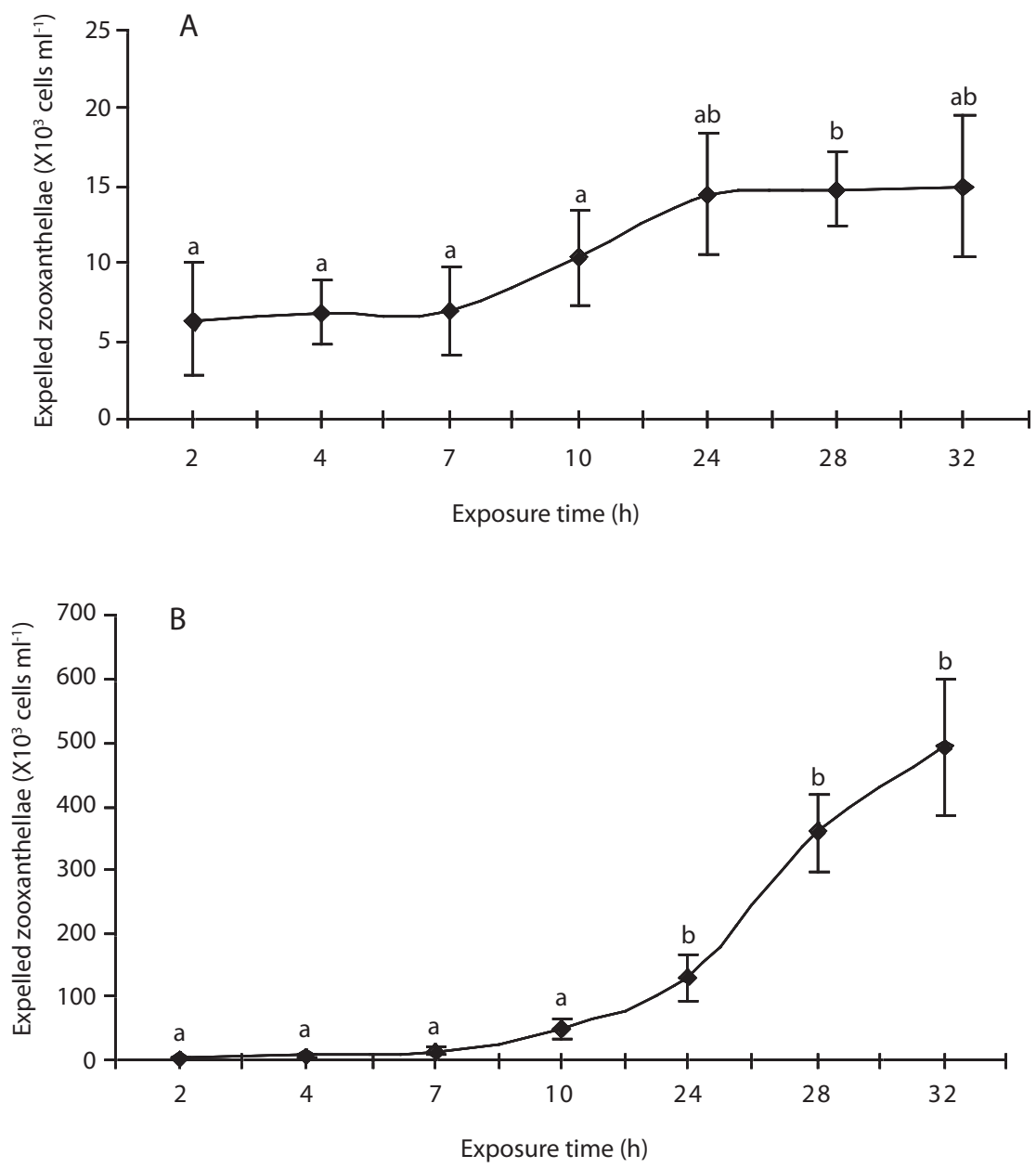

Fig. 2. Expulsion of zooxanthellae $\left(\times 10^{3}\right.$ cells $\left.\mathrm{ml}^{-1}\right)$ from Pocillopora capitata exposed to PAR and UVR light over $32 \mathrm{~h}$. (A) PAR treatment (B) UVR treatment. Data are mean \pm SD $(n=8)$. Means with different superscript are significantly different $(\mathrm{p}<0.05)$.

treatment there was no change in Chl $a$ but for CPs there was a significant decrease from $2 \mathrm{~h}$ onwards (Table 1 ). Whole pooled analyses (Table 2) revealed that corals exposed to UVR had significantly higher concentrations of Chl $a$ than PAR-treated corals; however, the CPs reduced their concentration in UVR-treated corals $(\mathrm{p}<0.01)$.

The $\mathrm{CP} / \mathrm{Chl} a$ ratio can be used as a sensitive indicator of photooxidative damage. As shown in Table 2, this ratio was significantly reduced in the UVR treatment $(\mathrm{p}<0.05)$ compared to the PAR treatment. On the other hand, the UVR treatment had a lower ratio at 4-10 and $28-32 \mathrm{~h}$, although this trend was only statistically significant at $32 \mathrm{~h}$ (Table 1 ).

Antioxidant enzymes: Comparison of antioxidant enzyme activities at the beginning and end of the experiment showed no significant between-treatment differences $(\mathrm{p}>0.05)$. When the pooled values were examined (Table 
TABLE 2

Whole pooled analysis of Chl a, CPS, CPS/Chl a ratio, MDA, SOD, CAT, GST and GPX in P. capitata exposed to PAR or UVR light over $32 \mathrm{~h}$

\begin{tabular}{|c|c|c|c|c|}
\hline & PAR & UVR & $\begin{array}{c}\text { Pooled } \\
\text { P-value (ANOVA) }\end{array}$ & $\mathrm{N}$ \\
\hline Chl $a\left(\mu \mathrm{g} \mathrm{cm}^{-2}\right)$ & $10.13 \pm 4.06$ & $13.55 \pm 6.50$ & $0.0210^{*}$ & 45 \\
\hline $\operatorname{CPs}\left(\mu \mathrm{g} \mathrm{cm}^{-2}\right)$ & $0.59 \pm 0.23$ & $0.22 \pm .08$ & $0.0000 *$ & 45 \\
\hline Rate CPs/Chl $a$ & $0.07 \pm .01$ & $0.02 \pm .009$ & $0.0000 *$ & 45 \\
\hline MAAs (pmol g-1 protein) & $19.10 \pm 7.61$ & $32.65 \pm 8.84$ & $0.0377 *$ & 24 \\
\hline MDA ( $\mu \mathrm{mol} \mathrm{g} \mathrm{g}^{-1}$ protein) & $3.40 \pm 0.84$ & $4.45 \pm 1.28$ & $0.0251 *$ & 15 \\
\hline $\mathrm{SOD}\left(\mathrm{U} \mathrm{mg}^{-1}\right.$ protein) & $682.64 \pm 345$ & $204.42 \pm 50.97$ & $0.0495 *$ & 6 \\
\hline CAT (U mg-1 protein) & $163.48 \pm 134.35$ & $381.63 \pm 299.51$ & 0.2752 & 6 \\
\hline GST (U mg-1 protein) & $6.19 \pm 3.05$ & $4.29 \pm 0.25$ & 0.2752 & 6 \\
\hline GPx(U mg-1 protein $)$ & $30.64 \pm 21.29$ & $27.35 \pm 17.53$ & 0.8273 & 6 \\
\hline
\end{tabular}

All values for each parameter were used to calculate a pooled mean. Significant differences $(\mathrm{P}<0.05)$ in the same row are marked with an asterisk.

2), only for SOD activity were significantly lower levels observed in the UVR treatment, although a similar but non-significant trend was observed for GST and GPX activities. In the PAR treatment, only CAT activity was elevated, but only slightly. In particular, as with high levels of this treatment, SOD activity was directly and inversely linked with Chl $a$ concentrations $\left(\mathrm{R}^{2}=0.96, \mathrm{p}=0.015\right)$ and numbers of expelled zooxanthellae $\left(\mathrm{R}^{2}=-0.91, \mathrm{p}=0.045\right)$. Also, the activities of GST and GPX were related to CPs levels $\left(\mathrm{R}^{2}=0.91, \mathrm{p}=0.041\right)$ and numbers of expelled zooxanthellae $\left(\mathrm{R}^{2}=-0.85\right.$, $\mathrm{p}=0.077$ ).

Lipid peroxidation (MDA): No significant differences were observed in the MDA concentrations among the sampling times in the two treatment groups (Fig. 3). However, relatively high MDA concentrations were evident at $28-32 \mathrm{~h}$ in the PAR treatment samples, and at 4-7, 24 and $28 \mathrm{~h}$ in the UVR treatment samples. Whole pooled analyses (Table 2 ) confirmed that UVR-treated corals had significantly higher

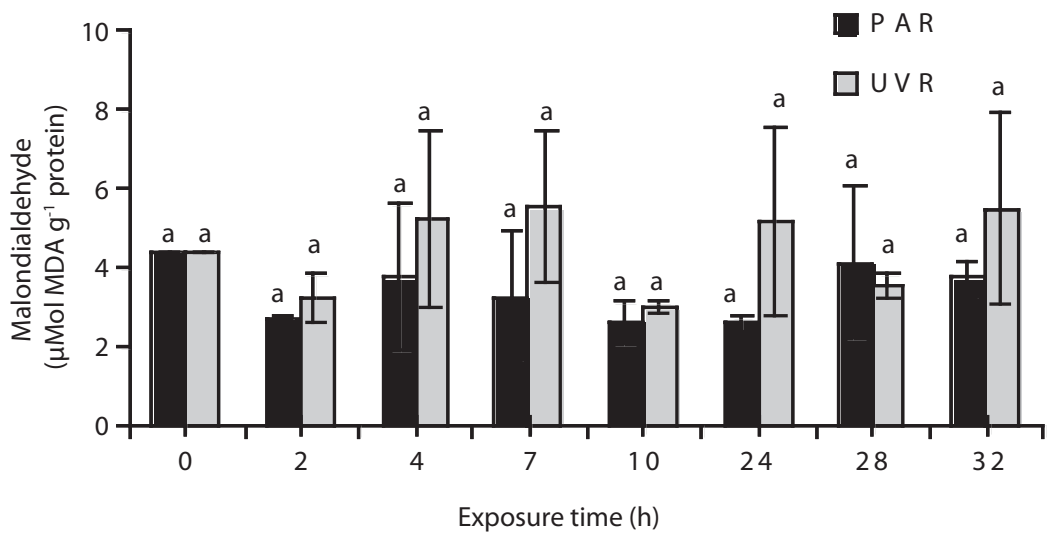

Fig. 3. Cellular damage ( $\mu \mathrm{mol} \mathrm{MDA} \mathrm{g}^{-1}$ protein) in Pocillopora capitata exposed to PAR and UVR light over 32h. Data are mean $\pm \mathrm{SD}(\mathrm{n}=3)$. Means with different superscript are significantly different $(\mathrm{p}<0.05)$. 
levels of lipid peroxidative damage than PARtreated corals $(\mathrm{p}<0.05)$.

Mycosporine-like amino acids (MAAs): No significant differences were observed in the concentration of total MAAs in PARtreated corals, although the highest concentration occurred at $7 \mathrm{~h}\left(43 \mathrm{pmolg}^{-1}\right.$ protein, $\mathrm{SD}=12.18, \mathrm{n}=2$ ). In contrast, a significantly higher concentration of total MAAs occurred at $4 \mathrm{~h}\left(89 \mu \mathrm{molg}^{-1}\right.$ protein, $\left.\mathrm{SD}=20.5, \mathrm{n}=2\right)$ in UVRtreated samples (Fig. 4). Levels of MAAs in the UVR treatment were significantly higher than in the PAR treatment (Table 2, $\mathrm{p}<0.05$ ).

\section{DISCUSSION}

Corals are exposed to varying light regimes depending on depth, location on the reef, and proximity to shade-casting colonies. Photoacclimation to different light regimes results in marked changes in the concentrations of photosynthetic pigments in endosymbiotic algae (Stambler \& Dubinsky 2004). Some changes are quite rapid, such as the amount of pigment in the algae or the sensitivity of the photosynthetic response, and some are slower, such as the characteristics, number, or even strain of zooxanthellae (Borneman 2001). We observed in PAR-treated corals higher levels of photosynthetic pigments at $4 \mathrm{~h}$, but after $7 \mathrm{~h}$, the levels were significantly lower possibly because the light stimulus used in this treatment corresponded to conditions prevailing during the early hours of the day and was thus low compared with the maximum light of the afternoon. The decline may therefore result from a deficiency in the light stimulus and natural light fluctuation. However, the UVR-treated corals had relatively low levels of carotenoids relative to $\mathrm{Chl} a$ concentrations, indicating that UVR caused damage to both the light-harvesting photosynthetic apparatus and the enzymes involved in carbon fixation (Warner et al. 1999, Jones et al. 2000). The CPs/Chl $a$ ratios were lower in the UVR-treated corals, which could indicate a relatively high degree of photooxidative damage (Hendry \& Price 1993, Gonçalves et al. 2001). Thus, low ratios in this treatment may be related to the progressive decrease of carotenoid pigments (Table 1); this decrease could be a non-enzymatic first line of defense against the pro-oxidant activity of ROS. Carotenoids not only destroy singlet oxygen $\left({ }^{1} \mathrm{O}_{2}\right)$, which causes oxidative damage to various biomolecules, but also prevent the formation of chlorophyll triplets in Photosystem II due to high radiation (Douglas 2003). This may represent a molecular strategy to

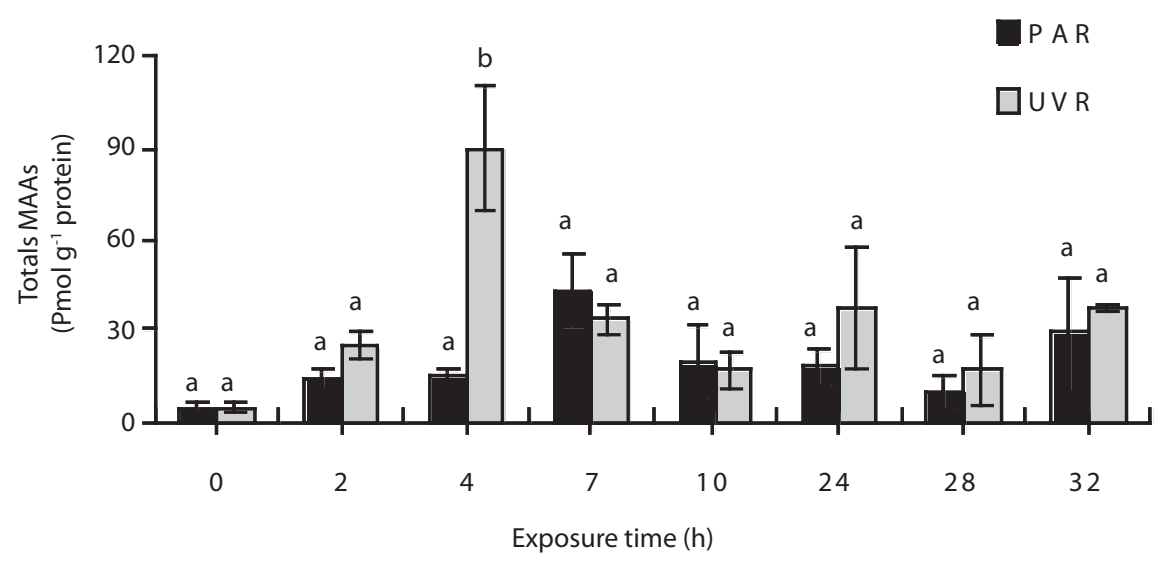

Fig. 4. Total concentration of MAAs (pmolg ${ }^{-1}$ protein) in Pocillopora capitata exposed to PAR and UVR light over $32 \mathrm{~h}$. Data are mean $\pm \operatorname{SD}(n=3)$. Means with different superscript are significantly different $(\mathrm{p}<0.05)$. 
prevent damage to diverse molecules, as well as the photosynthetic membranes.

In PAR treatment SOD activity was directly correlated with Chl $a$ and inversely linked with expelled zooxanthellae, and GST and GPX activities were directly related with CPs and expelled zooxanthellae. These relationships were not seen after UVR treatment and, for CAT activity, enzymatic antioxidant markers in this study generally showed lower activities in UVR-treated corals. $\mathrm{H}_{2} \mathrm{O}_{2}$ is relatively stable and has moderate reactivity and longevity. According to Scandalios et al. (1997), $\mathrm{H}_{2} \mathrm{O}_{2}$ reacts with metalloenzymes to cause loss of metal ions and decreases in catalytic activity. This potential interference may be accentuated by the high $\mathrm{H}_{2} \mathrm{O}_{2}$ concentrations formed during bleaching (Downs et al. 2002), as seen during the expulsion of zooxanthellae upon UVR treatment (Fig. 1b).

An alternative explanation for the low levels of antioxidant activity observed could be enzyme photoinactivation. Shindo \& Hashimoto (1997) studied the responses of different markers of stress in carnivore species exposed to UV-A radiation, and identified varying degrees of susceptibility of antioxidant enzymes to photoinactivation, related to the absorption of light by heme groups. Greater photoinhibition of CAT relative to SOD has also been observed in amphipods (Obermüller et al. 2005).

Although no significant differences were detected in CAT activity in the two treatments, this enzyme marker was the only one that exhibited a higher concentration in the UVR treatment. Scandalios et al. (1997) studied CAT gene expression patterns in plants and suggested that induction of $\mathrm{Cat}_{2}$ can be mediated by photoreceptors in the UV-A/blue and UV-B range. This assumes that the increase is due to the activity of zooxanthellar CAT. Thus, it may be that when UVR is used as a stressor, the action of enzymatic antioxidants is limited, and the contribution of non-enzymatic antioxidants to establish a balance between pro-oxidants and antioxidants becomes more relevant.

There is evidence that synthesis of MAAs is not maintained because production of these compounds represents an adaptive response to UVR exposure, requiring diversion of energy for growth (Moisan \& Mitchell 2001, Shick \& Dunlap 2002). On the other hand, the decreased concentration of carotenoid pigments is consistent with the observations of Obermüller et al. (2005), who studied the effects of UV-B on carotenoids in amphipods and reported a decrease in the concentration of these compounds prior to an event causing lipid peroxidation to the membrane and tissues. Our results confirm these observations in the sense that a decrease in the concentration of pigments was noted in the first two hours of UVR treatment. In this respect, Burton \& Ingold (1984) recognized the role of carotenoids reacting with lipid peroxidation products, and Mobley \& Gleason (2003) identified their importance as quenchers of oxygen radicals in algae and host animal cells.

In a previous study we exposed $P$. capitata to a gradual increase in temperature $\left(10^{\circ} \mathrm{C}\right)$ in vitro and found that lipid peroxidation $\left(0.9-2.7 \mu\right.$ molg $^{-1}$ protein) was lower in samples that had greater antioxidant activity (FloresRamírez \& Liñán-Cabello 2007). The average lipid peroxidation in PAR treatment $(3,4 \mu \mathrm{mol}$ $\mathrm{g}^{-1}$ protein) was similar to the reported by these authors, whereas the average of UVR treatment $\left(4,45 \mu \mathrm{mol} \mathrm{g}^{-1}\right.$ protein $)$ was superior to this value, but the levels of antioxidant activity decreased gradually and significantly during exposure to UVR. The greater lipid peroxidation associated to UVR treatment with respect to temperature changes confirms the report of Lesser \& Farrel (2004), that enhanced UVR further destabilizes photosynthetic machinery and thereby causes a high level of ROS with increased lipid peroxidation, photooxidative damage, and inhibition of metalloenzymes. Thus, carotenoid pigments in P. capitata may function to mitigate effects of thermal stress, but not to neutralize the effects of exposure to high UVR.

The coral reef at La Boquita is characterized by high exposure to radiation as a consequence of the shallow depth $(0.5-3.5 \mathrm{~m})$, with the largest population of coral occurring at an average depth of $0.75 \mathrm{~m}$. This population is 
subject to intense and constant stressors including input of warm waters of high salinity from the adjacent Juluapan Lagoon. In addition, low tides reduce the amount of suspended particles, causing greater exposure to sunlight (LiñánCabello et al. 2006). These stressors may act individually and/or synergistically. Rivers et al. (1998) conducted experiments with the coral Montastraea faveolata and reported that temperature plays a greater role in coral bleaching than UV-B radiation. However, when combined with exposure to high temperature, UV-B radiation became more important because the two stressors acted synergistically. According to Dykens et al. (1992), high light levels and UVR alone or in combination with elevated seawater temperatures lead to an increase in ROS both in symbiotic zooxanthellae and the coral host. It has been suggested that singlet oxygen produced in photosystem II (PSII) induces damage of the PSII machinery (Telfer et al., 1999).

The accumulation of MAAs is induced by UV radiation (UV-A and UV-B) and PAR (Scelfo 1986, Jokiel et al. 1997). In our experiments the maximum concentrations of MAA occurred at $4 \mathrm{~h}$ and $7 \mathrm{~h}$ after exposure to UVR and PAR, respectively (Fig. 3). This parallels the results of Carreto et al. (1990), who showed that exposure of the dinoflagellate Alexandium excavantum to high PAR resulted in the synthesis of MAA during the first 3-6h of exposure.

Torregiani \& Lesser (2007) recently reported that exposure of populations of the coral Montipora verrucosa originally collected at 1,5 , and $10 \mathrm{~m}$, when exposed to radiation equivalent to that received at $0.15 \mathrm{~m}$, resulted in the formation of high concentrations of MAAs in populations at $10 \mathrm{~m}$ depth and lowest DNA damage in response to exposure to UVR compared with those at shallow depths, but these authors did not determine MAA concentrations until the end of the experiment (three days), which could have masked an effect similar to that found in the first few hours of exposure in our experiments (Fig. 3).

Two scenarios have been proposed regarding the synthesis of MAAs in corals: (1) an increase in photosynthetic rates as a result of exposure to PAR leads to an increase in production of MAAs (Carreto et al. 1990, Shick et al 1999, Korbee et al. 2004); and (2) the biosynthesis of MAAs is unrelated to photosynthetic production, but rather is linked to other environmental, radiation and photomorphogenic factors (Shick et al. 1999, Moisan \& Mitchell 2001, Korbee et al. 2004, 2005). In this study, we obtained results indicative of both scenarios. The PAR treatment induced an increase in concentrations of photosynthetic pigments and an increase in the concentration of total MAAs. The UVR treatment yielded a significant increase in the concentration of MAAs over a shorter time (4h) that seen after PAR treatment ( $7 \mathrm{~h}$ to attain equivalent MAA levels), with no apparent relationship to photosynthesis. This may be a biochemical strategy for mitigating the biological effects of UVR, including damage to DNA, decreased photosynthetic ability and decreased coral growth (Lesser \& Lewis 1996, Lesser \& Farrell 2004).

There is evidence that exposure to UVR can cause damage to DNA through the formation of cyclobutane pyrimidine dimers (CPDs), which can cause genetic mutation and inhibition of RNA and DNA polymerase (Britt 1996). In a study of the alga Porphyra yezoensis, Misonou et al. (2003) noted that MAAs blocked the production of both 6-4 pyrimidine-pyrimidone photoproducts and CPDs formation. Torregiani \& Lesser (2007) showed that populations of the coral $M$. verrucosa exposed to radiation UVR at greater depth had increased capacity for MAA synthesis, and generated less CPDs compared to those at shallower depths. These findings suggest that MAAs not only quench ROS (Lesser 2006), but also form part of a complex molecular mechanism for protection against DNA damage.

Unlike the PAR treatment, in the UVRtreated corals there was an exponential increase in expulsion of zooxanthellae after seven hours exposure to UVR, but concentrations of MAAs decreased in both treatments. Similar expulsion was observed during the dark photoperiod. This suggests that generation of ROS and consequent 
tissue damage continued during the dark photoperiod, and that the buildup of ROS can only be attenuated by antioxidant compounds and/or enzymatic antioxidation (Goodsell 1996) and, consequently, the coral in the UVR treatment continued with the exponential expulsion of zooxanthellae (Fig. 2 A, B), although the UVR stimulus was suspended after dark.

According to Asada (1999), under natural physiological conditions cells exhibit different enzymatic and non-enzymatic capacities to remove ROS. However, with the UVR intensity and short duration of this experiment, a state of destabilized chronic photosynthetic electron transport could have been generated, as described by Stambler \& Dubinsky (2004), leading to irreversible damage to PSII in the UVR treatment despite removal of the UVR stressor. Several authors have observed that stress agents, such as radiation and high temperature, induce the generation of ROS by zooxanthellae, which leads to the expulsion of symbionts by the coral as a mechanism to reduce ROS in its tissues (Lesser 1997, Douglas 2003). These results in a reduction or loss of nutrients provided to the animal by the zooxanthellae (Jokiel \& Coles 1990, Warner et al. 1996, Downs et al. 2002, Douglas 2003).

Our experiments revealed a rapid response of coral to UVR stimulus. The biochemical mechanisms involved in the photosynthetic response were characterized by an initial decrease in the concentration of carotenoid pigments as a result of their role in counterbalancing the levels of ROS. Evidence of a rapid response was also apparent in increased synthesis of MAAs, which provides a source of antioxidant compounds and can also contribute to repair of DNA damage. However, the responses to UVR were not sufficient, even in the dark phase of the experiment, to mitigate the damage from ROS formation (greater in corals exposed to UVR than PAR), which caused a breakdown of the symbiotic relationship between the zooxanthellae and the host animal.

In this study, it could be possible to distinguish that, parallel to the short-term adjustments, such as the amount of pigment in the algae or the sensitivity of the photosynthetic response reported in other coral species, $P$. capitata exhibits a series of enzymatic responses oriented to resist the effects of ROS and therefore to adaptat to and maintain its reproductive capacity in shallow oceanic environments commonly exhibiting high levels of UVR. Nevertheless, as a result of the inappropriate location of the artificial intercommunication structure of the Juluapan Lagoon with respect to the arrecifal study area and therefore of the tidal influence, other variables such as the changes in short-time in turbidity, sediment inputs, nutrients, temperature and osmolarity, that can act in combination being able to cause irreversible damage. The implementation of a management plan for the coralline reefs of the Mexican Pacific coast is required.

\section{ACKNOWLEDGMENTS}

This project was supported by the PROMEP of the Secretary of Public Education, Mexico. We are grateful to Scott Butler (Managing Editor, English Manager Science Editing), for reviewing the English language and to Orlando Lugo Lugo and Paola Tenorio Rodríguez for their support in the biochemical analysis.

\section{RESUMEN}

Los arrecifes de coral se ven afectados por una serie de variables ambientales que afectan su crecimiento $\mathrm{y}$ supervivencia, siendo los principales factores la alta irradiación y las fluctuaciones de temperatura. Los especímenes de Pocillopora capitata Verrill 1864 fueron expuestos a radiación activa fotosintéticamente (PAR) y radiación ultravioleta (RUV) por $32 \mathrm{~h}$ en condiciones de laboratorio. Nosotros determinamos las concentraciones de peroxidación lipídica (MDA), actividades de enzimas antioxidantes (SOD, CAT, GPx y GST), clorofila a (Chl a), pigmentos carotenoides (CPS), aminoácidos tipo micosporina (MAAS), y la expulsión de las zooxantelas. Nuestros resultados muestran que los corales expuestos a los rayos UV presentaban niveles relativamente bajos de carotenoides y actividad de las enzimas antioxidantes en comparación con los expuestos al PAR, así como tasas de $\mathrm{CPs} / \mathrm{Chl}$ a bajas. Aunque MAAs y CPs se producen rápidamente como antioxidantes no enzimáticos en respuesta a la radiación ultravioleta en los corales, éstos no fueron 
suficientes, incluso en la fase oscura del experimento, para mitigar los daños causados por la formación de especies reactivas de oxígeno (ROS), lo que provocó una ruptura en la relación simbiótica entre las zooxantelas y el coral con una relación 33 veces mayor que en el tratamiento de PAR. A nivel enzimático, $P$ capitata presentó una serie de ajustes orientados a resistir los efectos derivados de la propagación de ROS y con ello favorecer su adaptación y capacidad reproductiva en ambientes oceánicos caracterizados por altos niveles de UVR.

Palabras clave: antioxidantes, coral, estrés oxidativo, MAAs, peroxidación lipidica, Pocillopora capitata, radiación activa fotosintética, SOD, CAT, GPx, GST, chlorofila $a$, especies reactivas de oxígeno.

\section{REFERENCES}

Aebi, H. 1984. Catalase in vitro. Methods Enzymol. 105: 121-126.

Anthony, K.R., S. R. Connolly \& O. Hoegh-Guldberg. 2007. Bleaching, energetics, and coral mortality risk: Effects of temperature, light, and sediment regime. Limnol. Oceanogr. 52:716-726.

Asada, K. 1999. The water-water cycle in chloroplasts: scavenging of active oxygen and dissipation of excess photons. Annu. Rev. Plant. Physiol. 50: 601-639.

Banaszak, A.T., M.G.B. Santos, T.C. Lajeunesse \& M.P. Lesser. 2006. The distribution of mycosporine-like amino acids (MAAs) and the phylogenetic identity of symbiotic dinoflagellates in cnidarian hosts from the Mexican Caribbean. J. Exp. Mar. Biol. Ecol. 337: 131-146.

Bandaranayake, W.M. 1998. Mycosporines: are they nature's sunscreens? Nat. Prod. Rep. 15: 159-172.

Borneman, E.H. 2001. Aquariums corals: Selection, husbandry and natural history. T.F.H. Publications, Neptune, New Jersey, USA. 464p.

Bradford, M.M. 1976. A rapid and sensitive method for the quantification of microgram quantities of protein utilizing the principle of protein-dye binding. Anal. Biochem. 72: 248-254.

Britt, A. 1996. DNA damage and repair in plants. Annu. Rev. Plant Physiol. Plant Mol. Biol. 47: 75-100.

Buege, J.A. \& D. Aust. 1978. Microsomal lipid peroxidation. Methods Enzymol. 51: 302-310.

Burton, G.W. \& K.U. Ingold. 1984. Beta-carotene: an unusual type of lipid antioxidant. Science 224: 569573.
Carreto, J.I., V.A. Lutz, S.G. De Marco \& M.O. Carignan. 1990. Fluence and wavelength dependence of mycosporine-like amino acids synthesis in the dinoflagellate Alexandrium excavatum, p. 275-279. In E. Granéli, B. Sunström, L. Edler \& D.M. Anderson (eds). Toxic marine phytoplankton. Amsterdam, Netherlands.

Cockell, C.S. \& J. Knowland. 1999. Ultraviolet radiation screening compounds. Biol. Rev. 74: 311-345.

Douglas, A.E. 2003. Coral bleaching how and why? Mar. Poll. Bull. 46: 385-392.

Downs, C.A., J.E. Fauth, J. Halas, P. Dustan, J. Bemiss \& C.M. Woodley. 2002. Oxidative stress and seasonal coral bleaching. Free Radic. Biol. Med. 33: 533543

Dunlap, W.C. \& J.M. Shick. 1998. UV radiation absorbing mycosporine-like amino acids in coral reef organisms: A biochemical and environmental perspective. J. Phycol. 34: 418-430.

Dunlap, W.C. \& Y. Yamamoto. 1995. Small-molecule antioxidants in marine organisms: antioxidant activity of mycosporine-glycine. Comp. Biochem. Physiol. B. 112: $105-114$.

Dykens, J.A., J.M. Shick, C. Benoit, G.R. Buettner \& Winston G.W. 1992. Oxygen radical production in the sea anemone Anthopleura elegantissima and its symbiotic algae. J. Exp. Biol. 168: 219-241.

Flohé, L.A. \& W.A. Günzler. 1984. Assays for glutathione peroxidase. Meth. Enzymol. 105: 114-120.

Flores-Ramírez, L. \& M.A. Liñán-Cabello. 2007. Relationships among thermal stress, bleaching and oxidative damage in the hermatypic coral, Pocillopora capitata. Comp. Biochem. Physiol. C. 146: 194-202.

Girotti, A.W. 1998. Lipid hydroperoxide generation, turnover, and effector action in biological systems. J. Lipid Res. 39: 1529-1542.

Gonçalves, J.F., R.A. Marenco \& G. Vieira. 2001. Concentration of photosynthetic pigments and chlorophyll fluorescence of mahogany and tonka bean under two light environments. R. Bras. Fisiol. Veg. 13: 149-157.

Goodsell, D.S. 1996. Our molecular nature: The body's motors, machines and messages. Springer-Verlag, New York, EEUU. 183 p.

Habig, W.H. \& W.B. Jakoby. 1981. Glutathione S-transferases (rat and human). Meth. Enzymol. 77: 218-235. 
Hendry, G.A.F. \& A.H. Price. 1993. Stress indicators: Chlorophylls and carotenoids, p. 148-152. In G.A.F. Hendry \& J.P. Grime (eds). Methods in Comparative Plant Ecology. A laboratory Manual. London, England, U.K

Johannes, R.E. \& W.J. Wiebe. 1970. Method for determination of coral tissue biomass and composition. Limnol. Oceanogr. 15: 822-824.

Jokiel, P.L. \& S.L. Coles. 1990. Response of Hawaiian and other Indo-Pacific reef corals to elevated temperature. Coral Reefs 8: 155-162.

Jokiel, P.L., M.P. Lesser \& M.E. Ondrusek. 1997. UVabsorbing compounds in the coral Pocillopora damicornis: Interactive effects of UV radiation, photosynthetically active radiation, and water flow. Limnol. Oceanogr. 42: 1468-1473

Jokiel, P.L. \& R.H. York. 1982. Solar ultraviolet photobiology of the reef coral Pocillopora damicornis and symbiotic zooxanthellae. Bull. Mar. Sci. 32: 301-315.

Jones, R.J., S. Ward, A.Y. Amri \& O. Hoegh-Guldberg. 2000. Changes in quantum efficiency of Photosystem II of symbiotic dinoflagellates after heat stress, and of bleached corals sampled after the 1998 Great Barrier Reef mass bleaching event. Mar. Freshw. Res. 51: 63-71.

Karsten, U., T. Sawall \& C. Wiencke. 1998. A survey of the distribution of UV-absorbing substances in tropical macroalgae. Phycol. Res. 46: 271-279.

Kinzie, R. 1993. Effects of ambient levels of solar ultraviolet radiation on zooxanthellae and photosynthesis of the coral Montipora verrucosa. Mar. Biol. 116: 319-327.

Korbee, N., R. Abdala, F. Figueroa \& E.W. Helbling. 2004. Ammonium and UV radiation stimulate the accumulation of mycosporine-like amino acids in Porphyra columbina (rhodophyta) from Patagonia, Argentina. J. Phycol. 40: 248-259.

Korbee, N., F. Figueroa \& J. Aguilera. 2005. Effect of light quality on the accumulation of photosynthetic pigments, proteins and mycosporine-like amino acids in the red alga Porphyra leucosticta (Bangiales, Rhodophyta). J. Photochem. Photobiol. B. Biol. 80: 71-78.

Korbee, N., F. Figueroa \& J. Aguilera. 2006. Acumulación de aminoácidos tipo micosporina (MAAs): Biosíntesis, fotocontrol y funciones ecofisiológicas. Rev Chil. Hist. Nat. 79: 119-132.
Lesser, M.P. 1996. Elevated temperatures and ultraviolet radiation cause oxidative stress and inhibit photosynthesis in symbiotic dinoflagellates. Limnol. Oceanogr. 41: 271-283.

Lesser, M.P. 1997. Oxidative stress causes coral bleaching during exposure to elevated temperatures. Coral Reefs 16: 197-192.

Lesser, M.P. 2000. Depth-dependent photoacclimatization to solar ultraviolet radiation in the Caribbean coral Montastraea faveolata. Mar. Ecol. Prog. Ser. 192: 137-151.

Lesser, M.P. 2004. Experimental biology of coral reef ecosystem. J. Exp. Mar. Biol. 300: 217-252.

Lesser, M.P. 2006. Oxidative stress in marine environments: biochemistry and physiological ecology. Annu. Rev. Physiol. 68: 253-278.

Lesser, M.P. \& J.H. Farrel. 2004. Exposure to solar radiation increases damage to both host tissues and algal symbionts of coral during thermal stress. Coral reefs 23: $367-377$.

Lesser, M.P. \& S. Lewis. 1996. Action spectrum for the effects of UV radiation on photosynthesis in the hermatypic coral Pocillopora damicornis. Mar. Ecol. Prog. Ser. 134: 171-177.

Lesser, M.P. \& J.M. Shick. 1989. Effects of irradiance and ultraviolet radiation on photoadaptation in zooxanthellae of Aiptasia pallida: Primary production, photoinhibition, and enzymic defenses against oxygen toxicity. Mar. Biol. 102: 243-255.

Liñán-Cabello, M.A., L. Flores-Ramírez, J.S. ZacaríasSalinas, O. Hernández-Rovelo \& C. Lezama-Cervantes. 2006. Correlation of chlorophyll $a$ and total carotenoid concentrations with coral bleaching from locations on the Pacific coast of Mexico. Mar. Fresh. Behav. Physiol. 39: 279-291.

Misonou, T., J. Saitoh, S. Oshiba, Y. Tokitomo, M. Maegawa, Y. Inoue, H. Hori \& T. Sakurai. 2003. UV-absorbing substance in the red alga Porphyra yezoensis (Bangiales, Rhodophyta) plock thymine dimer production. Mar. Biotechnol. 5: 194-200.

Mitchell, D.L. \& D. Karentz. 1993. The induction and repair of DNA photodamage in the environment, $\mathrm{p}$. 345-377. In A.R.Young, L.O. Björn, J. Moan \& W. Nultsch (eds). Environmental UV Photobiology. New York, New York, EEUU.

Mobley, K.B. \& F. Gleason. 2003. The effect of light and heterotrophy on carotenoid concentrations in the 
Caribbean anemone Aiptasia pallida (Verril). Mar. Biol. 143: 629-637.

Moisan, T.A. \& B.G. Mitchell. 2001. UV absorption by mycosporine-like amino acids in Phaeocystis antarctica Karsten induced by photosynthetically available radiation. Mar. Biol. 138: 217-227.

Murguía-Vega, A. \& H. Reyes-Bonilla. 1999. Concentración de clorofila a en colonias de Pocillopora verrucosa (Scleractina) durante un blanqueamiento coralino en el Golfo de California, México. Rev. Biol. Trop. 47: 677-680.

Obermüller, B., U. Karsten \& D. Abele. 2005. Response of oxidative stress parameters and sunscreening compounds in Arctic amphipods during experimental exposure to maximal natural UVB radiation. J. Exp. Mar. Biol. Ecol. 323: 100-117.

Parsons, T.R., Y. Maita \& C.M. Lalli. 1984. A manual of chemical and biological methods for sea water analysis. Pergamon, Oxford, England, U.K. 173 p.

Reyes-Bonilla, H., L. Calderón-Aguilera, G. Cruz-Piñon, P. Medina-Rosas, R.A. López-Pérez, M.D. Herrero-Pérezrul, G. Leyte-Morales, A. Cupul-Magaña, J. Carriquiry-Beltrán. 2005. Atlas de los corales pétreos (Scleractinia) del Pacífico Mexicano. CICESE/CONABIO/CONACYT/UABSC, Universidad de Guadalajara, Universidad del Mar, México. 124 p.

Riegger, L. \& D. Robison. 1997. Photoinduction of UVabsorbing compounds in Antarctic diatoms and Phaeocystis antarctica. Mar. Ecol. Prog. Ser. 160: 13-25.

Rivers, T., E. Macri \& A. Miller. 1999. The effects of elevated UV-B radiation on productivity and bleaching of zooxanthellae in the coral Montastraea Faveolata. Algal Symposium May 1999. Yachats, Oregon, EEUU.

Scandalios, J.G., L. Guan \& A.N. Polidoros. 1997. Catalases in plants: Gene structure properties, regulation, and expression, p. 343-406. In J.G. Scandalios (eds). Oxidative stress and molecular biology of antioxidant defenses. North Carolina, EEUU.

Scelfo, G.M. 1986. Relationship between solar radiation and pigmentation of the coral Montipora verrucosa and its zooxanthellae, p. 440-451. In P.L. Jokiel, R.H. Richmond, \& R.A. Rogers (eds). Coral reef population biology: Tech Report 37. Hawaii Institute of Marine Biology, Honolulu Hawaii, EEUU.

Sheskin, D.J. 1996. Handbook of parametric and nonparametric statistical procedures. CRC Press, Boca Raton, Florida, EEUU. 719 p.
Shick, J.M. \& W.C. Dunlap. 2002. Mycosporine-like amino acids and related gadusols: biosynthesis, accumulation, and UV-protective function in aquatic organisms. Annu. Rev. Physiol. 64: 223-262.

Shick, J.M., W.C. Dunlap, B.E. Chalker, A.T. Banaszak \& T.K. Rosenzweig. 1992. Survey of ultraviolet radiation-absorbing mycosporine-like amino acids in organs of coral reef holothuroids. Mar. Ecol. Prog. Ser. 90:139-148.

Shick, M., M.P. Lesser \& P.L. Jokiel. 1996. Effects of ultraviolet radiation on corals and other coral reef organisms. Global Change Biol. 2: 527-545.

Shick, J.M., S. Romaine-Lioud, C. Ferrier-Pagès \& J.P Gattuso. 1999. Ultraviolet-B radiation stimulates shikimate pathway-dependent accumulation of mycosporine-like amino acids in the coral Stylophora pistillata despite decreases in its population of symbiotic dinoflagellates. Limnol. Oceanogr. 44: 1667-1682.

Shindo, Y. \& T. Hashimoto. 1997. Time course of changes in antioxidant enzymes in human skin fibroblast after UVA irradiation. J. Dermatol. Sci. 3: 255-232.

Smith, S.V. 1978. Coral reef area and contribution to processes and resources of the world's oceans. Nature 273: 225-226.

Sommer, T.R., F.M.L. D’Souza \& N.M. Morrissy. 1992. Pigmentation of adult rainbow trout Oncorhnchus mykiss, using the green alga Hematococcus pluvialis. Aquaculture 106: 63-74.

Stambler, N. \& Z. Dubinsky. 2004. Stress effects on metabolism and photosynthesis of hermatypic corals, p. 195-215. In E. Rosenberg, \& Y. Loya (eds). Coral Health and Disease. Berlin, Germany.

Suh, H.J., H.W. Lee \& J. Jung. 2003. Mycosporine glycine protects biological systems against photodynamic damage by quenching singlet oxygen with a high efficiency. Photochem. Photobiol. 78: 109-113.

Suzuki, K. 2000. Measurement of Mn-SOD and Cu, ZnSOD, p. 91-95. In N. Taniguchi, J. Gutteridge (eds). Experimental Protocols for Reactive Oxygen and Nitrogen Species. Oxford University Press, Oxford, England, U.K.

Telfer, A., T.C. Oldham, D. Phillips \& J. Barber. 1999. Singlet oxygen formation detected by near-infrared emission from isolated photosystem II reaction centres: direct correlation between P680 triplet decay and luminescence rise kinetics and its consequences 
for photoinhibition. J. Photochem. Photobiol. 48: 89-96.

Torregiani, J.H. \& M.P. Lesser. 2007. The effects of short-term exposures to ultraviolet radiation in the Hawaiian Coral Montipora verrucosa. J. Exp. Mar. Biol. Ecol. 340: 194-203.

Van de Poll, W.H., A. Eggert, A.G.J. Buma \& A.M. Breeman. 2001. Effects of UV-B-induced DNA damage and photoinhibition on growth of temperate marine red macrophytes: habitat-related differences in UV-B tolerance. Plant Cell Environ J. Phycol. 37: 30-37.

Warner, M.E., W.K. Fitt \& G. Schmidt. 1996. The effects of elevated temperature on the photosynthetic efficiency of zooxanthellae in hospite from four different species of reef corals: A novel approach. Plant Cell Environ. 19: 291-299.

Warner, M.E., W.K. Fitt \& G.W. Schmidt. 1999. Damage to photosystem II in symbiotic dinoflagellates: a determinant of coral bleaching. Proc. Natl. Acad. Sci. USA 96: 8007-8012.

Wilkinson, C.R. 2000. Status of coral reefs of the world: 2000. Global Coral Reef Monitoring Network and Australian Institute of Marine Science. Townsville, Queensland, Australia, 363 p.

Wilkinson, C.R. 2002. Status of coral reefs of the world: 2002. Global Coral Reef Monitoring Network and Australian Institute of Marine Science. Townsville, Queensland, Australia, 388 p. 